\title{
Obituary
}

Cytogenetic and GenomeResearch
Accepted: September 28, 2018

Published online: October 17, 2018

\section{Michael Schmid (1948-2018): A Life Devoted to Science}

A native of Aschaffenburg, Germany, Michael Schmid received his primary and secondary education in Caracas, Venezuela. Having to witness the social and economic downfall of his beloved Venezuela during recent years almost broke his heart. Early on, Michael became fascinated by and attracted to the abundant flora and fauna of the Caribbean paradise. As a high school student, he started observing, collecting, and describing butterflies leading to the publication of his first book [Schmid and Endicott, 1968]. So it was no surprise that Michael became a student of biology, first at Harvard, then at Basel and Freiburg. Under the guidance of Winfried Krone and Ulrich Wolf, he started his cytogenetics career by studying the nucleolus organizing chromosomes of the human karyotype. His thesis work resulted in his first Nature paper [Schmid and Krone, 1975], reporting the discovery of an acrosomal chromocenter in the spermatogenesis of Amphibia - by good chance a model organism in the Department of Human Genetics at the University of Ulm where he had moved.

Forty years ago, Michael published the first of a by now legendary series of 37 papers entitled "Chromosome Banding in Amphibia" [Schmid, 1978]. These papers have become a sort of trademark for the perfection (if not art) by which he characterized and classified amphibian

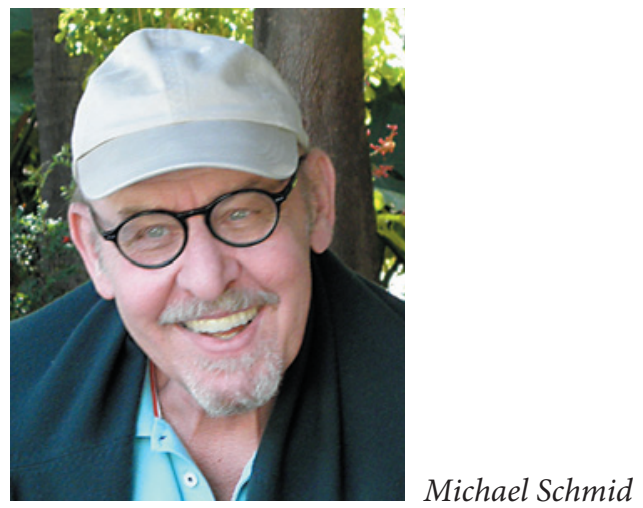

karyotypes. After receiving his $\mathrm{PhD}$ degree in Human Biology, he joined the group of Wolfgang Engel in Göttingen, a human genetics laboratory dedicated to studying physiology and pathology of human spermatogenesis. It was the good fortune of the newly founded Department of Human Genetics at the University of Würzburg School of Medicine that we were able to recruit Michael Schmid, in 1981, as head of the future lab of Experimental, Comparative, and Clinical Cytogenetics. What prompted Michael to give up his productive work in Göttingen and move to Würzburg? He probably sensed that he would be 
able to pursue his very own research interests and ideas, contrary to German tradition, without interference by the Department Chair. He also knew that work on model organisms would be welcome as integral part of the scientific endeavors of his colleagues at the new Würzburg Biocenter where his lab would be located. Indeed, there could have been no better place for a biologically oriented young investigator on his way to scientific independence than being embedded in a group of biologists working on diverse model systems including Drosophila (Martin Heisenberg), ants (Bert Hölldobler), and fish (Manfred Schartl). In his quiet but enthusiastic way, Michael built up his lab and embarked on a variety of research projects, ranging from human chromosome pathology to evolutionary aspects of piscean, avian, and amphibian karyotypes and genomes.

At the time, various ways of how to induce banding patterns on chromosomes and the technique of multicolor spectral karyotyping had already revolutionized human and mammalian cytogenetics. Gene mapping by in situ hybridization and the technique of genetic fingerprinting started to close the gap between the light microscopic and the molecular level. Despite Michael's obvious preference for the as yet largely uncharted territory of lower vertebrate chromosomes, he never lost sight of and responded energetically to the increasing demand of diagnostic cytogenetics, as evidenced by more than 50 clinical case reports describing how both constitutional and somatic mutations may cause infertility, spontaneous abortion, congenital malformations, mental retardation, and cancerous growth. Parallel to this "bread and butter" work of obvious clinical relevance, Michael applied the new techniques to more fundamental questions in human genetics, answering important questions such as (to name a few): induction, distribution, nature, and conservation of fragile sites in primate chromosomes [Schmid et al., 1985], whether and how chromosome pairing occurs in human somatic cells [Haaf et al., 1986], and to what extent aneuploidy of certain chromosomes occurs as a function of donor age, both in somatic [Guttenbach et al., 1995] and in male germ cells [Guttenbach and Schmid, 1990; Buwe et al., 2005]. Together with one of his most gifted doctoral students (Thomas Haaf), Michael Schmid established and explored the new field of "immunocytogenetics," visualizing antibodies directed against specific chromosomal sites (kinetochores, telomeres, or nucleolus organizer regions, NORs) via indirect immunofluorescence. Even though variable antibody quality rendered this elegant technique unreliable, Haaf and Schmid were able to prove that the number of actively transcribed rRNA genes (within the NORs) remains constant in somatic cells of all vertebrates, regardless of how many rRNA genes are present in a given species [Haaf et al., 1991].

Michael Schmid's bibliography comprises more than 400 publications, including reviews and contributions to symposium volumes and books. These publications mostly reflect the results of focused research, but a few also reflect the good fortune of serendipity, such as the reports on the highest chromosome number in mammals [Schmid et al., 1988] or the lowest chromosome number in reptiles [Schmid et al., 1994]. To this category also belong single papers on the chromosome constitution of the Turkish desert woodlouse [Röder et al., 1993] or of orchid bees [Eltz et al., 1997]. Roughly 25\% of Michael's bibliography deal with human mitotic and meiotic chromosomes in health and disease, representing the human genetics side of his interests. Another $25 \%$ focus on structure, function, and evolution of vertebrate sex chromosomes, including sex-determining genes. These studies extend over a period of more than 30 years and have yielded important insights: most of the cold-blooded animals (fish, amphibians, and reptiles) possess homomorphic gonosomes, while warmblooded animals always have heteromorphic gonosomes, either XY (mammals) or ZW (birds). As Manfred Schartl, Michael Schmid, and their coworkers could show, initial steps during the evolution of the gonosome pair consisted in the accumulation of repetitive DNA sequences in the primitive $\mathrm{Y}$ or $\mathrm{W}$ chromosomes whereby meiotic crossover in the respective gonosome pair is gradually reduced and all but prevented [Nanda et al., 1993]. Another important result of these studies is the fact that genetic inactivation is limited to one $\mathrm{X}$ of the homomorphic X pair in female mammals but neither occurs in the homomorphic $\mathrm{Z}$ pair of male birds, nor in gonosomes of fish, amphibians or reptiles. The likely mechanism of sex determination in birds was clarified by a landmark study of the Schmid lab assigning the DMRT1 gene to the avian $\mathrm{Z}$ chromosome, whereas the W chromosome lacks this gene [Nanda et al., 1999]. As in Drosophila and C. elegans, male sex in birds is therefore determined by a double dose of Z-linked genes, notably DMRT1. In response to creationist attacks, Michael liked to refer to his Nature Genetics paper showing that the short arm of human chromosome 9 and the avian $\mathrm{Z}$ chromosome exhibit a striking degree of genetic identity despite their divergence 300 million years ago. In the meantime, Indrajit Nanda mapped the avian homologs of the human FANCG and FANCC genes on the
2

Cytogenet Genome Res 2018;156:1-4 DOI: $10.1159 / 000494232$
Höhn 
avian $\mathrm{Z}$, suggesting that double dosage of genes crucial for DNA repair might explain the greater longevity of the male (ZZ) compared to the female (ZW) sex in avian species [Nanda et al., 2007].

Between 1990 and 2014 (when the chicken genome was fully sequenced), Michael Schmid's group took the lead in mapping genes to chicken chromosomes via in situ hybridization. Several important insights were gained from these studies: (1) Contrary to expectation, the gene density on avian microchromosomes was found to exceed that of avian macrochromosomes [DominguezSteglich et al., 1993]. (2) Avian ZW gonosomes must have arisen from a different pair of ancestral autosomes than the mammalian XY pair [Schmid et al., 2000]. (3) Akin to the mammalian $\mathrm{X}$ chromosome, the avian $\mathrm{Z}$ chromosome is highly conserved during evolution [Nanda and Schmid, 2002]. (4) Avian imprinted genes are localized on macrochromosomes and exhibit asynchronous replication [Dünzinger et al., 2005]. (5) As already mentioned, in light of a 300-million-year divergence, the conserved synteny between the avian $\mathrm{Z}$ and human chromosome 9 is striking [Nanda et al., 1999]. In order to collect the fastgrowing amount of data on the chicken genome, Michael initiated an international collaborative network and coordinated the publication of three comprehensive status reports, widely known as first, second, and third "Report on Chicken Genes and Chromosomes" [Schmid et al., 2000, 2005, 2015]. A truly admirable and internationally successful effort by Michael's relatively small but highly motivated group.

In looking back at Michael Schmid's scientific oeuvre, there is little doubt that it was crowned, very recently, by the publication of three volumes of encyclopedic character, summarizing his nearly life-long interest and research in amphibian species [Schmid et al., 2010, 2012, 2018]. Scientific giants in the fields of herpetology, evolution, and animal genetics (James Bogart, Blair Hedges, and William Duellman) joined and supported Michael's tremendous effort. Together with his longtime coworkers Claus Steinlein and Wolfgang Feichtinger, Michael undertook a total of 13 field trips, mostly to Central and South American countries and to Australia, in order to collect specimens for his long-term scientific goal: to establish a comprehensive catalogue of amphibian chromosomes in order to understand the evolutionary principles which render these species so abundant and so successful in their adaptation to different environments. In talking to Michael a few years ago, he laughingly admitted that, contrary to what he had hoped for, he had only been able to uncover the tip of the iceberg of the

Obituary incredibly vast and diverse amphibian world. It is probably fair to say that even the tip of the iceberg that Michael and his colleagues have uncovered gives food for thought for many years to come, including the sad realization of how human destruction of animal habitats threatens the existence of a growing number of species. Even though new anuran species will occasionally still be discovered in remote places, their discovery will appropriately be reported in the Journal of Threatened Taxa [Kaiser et al., 2015].

What will Michael's legacy be, in addition to his many publications? Over the years, there were more than thousand students who took his legendary hands-on course in cytogenetics, learning how to prepare and analyze their own chromosomes and those of a variety of animal species. His enthusiasm as an academic teacher will remain in the heads of these students even though karyotyping will soon be replaced by whole-genome sequencing. There is also the memory of the many authors who submitted their manuscripts to the various journals edited or co-edited by Michael Schmid. Journals like Cytogenetic and Genome Research, Sexual Development, and Molecular Syndromology will remain connected with Michael's name and his friendly and professional way of corresponding with authors. In the Department of Human Genetics, his legacy will continue embodied by his most prolific student, Thomas Haaf, the current Department Chair. In the history of cytogenetics, both human and animal, Michael will be remembered as a contemporary Alexander von Humboldt, who described and discovered miracles of the living world that less gifted people often fail to see.

Michael Schmid died in August 2018 shortly after his 70th birthday. He is survived by his wife and editorial assistant, Karin, and two sons.

Holger Höhn Würzburg, Germany 


\section{References}

Buwe A, Guttenbach M, Schmid M: Effect of paternal age on the frequency of cytogenetic abnormalities in human spermatozoa. Cytogenet Genome Res 111:213-228 (2005).

Dominguez-Steglich M, Robbins J, Schmid M: Mapping of the chicken N-CAM gene and a myosin heavy chain gene: avian microchromosomes are not genetically inert reserves of DNA. J Exp Zool 265:295-300 (1993).

Dünzinger U, Nanda I, Schmid M, Haaf T, Zechner U: Chicken orthologues of mammalian imprinted genes are clustered on macrochromosomes and replicate asynchronously. Trends Genet 21:488-492 (2005).

Eltz T, Schmid M, Roubik DW: Haploid karyotypes of two species of orchid bees (Hymenoptera: Apidae, Euglossini). J Kansas Entomol Soc 70:142-144 (1997).

-Guttenbach M, Schmid M: Determination of Y chromosome aneuploidy in human sperm nuclei by nonradioactive in situ hybridization. Am J Hum Genet 46:553-558 (1990).

Guttenbach M, Koschorz B, Bernthaler U, Grimm T, Schmid M: Sex chromosome loss and aging: in situ hybridization studies on human interphase nuclei. Am J Hum Genet 57:11431150 (1995).

-Haaf T, Steinlein K, Schmid M: Preferential somatic pairing between homologous heterochromatic regions of human chromosomes. Am J Hum Genet 38:319-329 (1986).

-Haaf T, Hayman DL, Schmid M: Quantitative determination of rDNA transcription units in vertebrate cells. Exp Cell Res 193:78-86 (1991).

Kaiser H, Barrio-Amorós CL, Rivas GA, Steinlein C, Schmid M: Five new species of Pristimantis (Anura, Strabomantidae) from the coastal cloud forest of the Península de Paria, Venezuela. J Threatened Taxa 7:7047-7088 (2015).

Nanda I, Schmid M: Conservation of avian Z chromosomes as revealed by comparative mapping of the Z-linked aldolase B gene. Cytogenet Genome Res 96:176-178 (2002).

Nanda I, Schartl M, Epplen JT, Feichtinger W, Schmid M: Primitive sex chromosomes in poeciliid fishes harbor simple repetitive DNA sequences. J Exp Zool 265:301-308 (1993).

Nanda I, Shan Z, Schartl M, Burt DW, Koehler M, Nothwang H-G, Grützner F, Paton IR, Windsor D, Dunn I, Engel W, Staeheli P, Mizuno S, Haaf T, Schmid M: 300 million years of conserved synteny between chicken $Z$ and human chromosome 9. Nat Genet 21:258259 (1999).
Nanda I, Buwe A, Winzenmann A, Takata M, Haaf T, Schartl M, Schmid M: Fanconi anemia genes in vertebrates: evolutionary conservation, sex-linkage, and embryonic expression of FANCC and FANCG in avian cells, in Schindler D, Hoehn H (eds): Monographs of Human Genetics, vol VI, Fanconi Anemia, pp 183-199 (S. Karger, Basel 2007).

-Röder G, Steinlein C, Schmid M, Linsenmair KE: Karyotype and chromosome banding in the Turkish desert woodlouse Desertellio elongatus (Crustacea, Isopoda, Oniscidea). Experientia 49:339-341 (1993).

Schmid M: Chromosome banding in Amphibia. I. Constitutive heterochromatin and nucleolus organizer regions in Bufo and Hyla. Chromosoma 66:361-388 (1978).

Schmid M, Endicott BM: Mariposas de Venezuela (L. Levison Junr. LTD, Copenhagen 1968).

Schmid M, Krone W: Acrosomal chromocentre in newt spermiogenesis. Nature 257:795-797 (1975).

Schmid M, Ott G, Haaf T, Scheres JMJC: Evolutionary conservation of fragile sites induced by 5 -azacytidine and 5 -azadeoxycytidine in man, gorilla, and chimpanzee. Hum Genet 71: 342-350 (1985).

-Schmid M, Fernández-Badillo A, Feichtinger W, Steinlein C, Roman JI: On the highest chromosome number in mammals. Cytogenet Cell Genet 49:305-308 (1988).

Schmid M, Feichtinger W, Nanda I, Schakowski R, Visbal García R, Manzanilla Puppo J, Fernández Badillo A: An extraordinarily low diploid chromosome number in the reptile Gonatodes taniae (Squamata, Gekkonidae). J Hered 85:255-260 (1994).

Schmid M, Nanda I, Guttenbach M, Steinlein C, Hoehn H, Schartl M, Haaf T, Weigend S, Fries R, Buerstedde JM, Wimmers K, Burt DW, Smith J, A'Hara S, Law A, Griffin DK, Bumstead N, Kaufman J, Thomson PA, Burke TA, Groenen MAM, Crooijmans RPMA, Vignal A, Fillon V, Morisson M, Pitel F, Tixier-Boichard M, Ladjali-Mohammedi K, Hillel J, Mäki-Tanila A, Cheng HH, Delany ME, Burnside J, Mizuno S: First report on chicken genes and chromosomes 2000. Cytogenet Cell Genet 90:169-218 (2000).

Schmid M, Nanda I, Hoehn H, Schartl M, Haaf T, Buerstedde JM, Arakawa H, Caldwell RB, Weigend S, Burt DW, Smith J, Griffin DK, Masabanda JS, Groenen MAM, Crooijmans RPMA, Vignal A, Fillon V, Morisson M, Pitel F, Vignoles M, Garrigues A, Gellin J, Rodi- onov AV, Galkina SA, Lukina NA, Ben-Ari G, Blum S, Hillel J, Twito T, Lavi U, David L, Feldman MW, Delany ME, Conley CC, Fowler VM, Hedges SB, Godbout R, Katyal S, Smith C, Hudson Q, Sinclair A, Mizuno S: Second report on chicken genes and chromosomes 2005. Cytogenet Genome Res 109:415479 (2005).

Schmid M, Steinlein C, Bogart JP, Feichtinger W, León P, La Marca E, Díaz LM, Sanz A, Chen $\mathrm{SH}$, Hedges SB: The chromosomes of terraranan frogs. Insights into vertebrate cytogenetics. Cytogenet Genome Res 130/131:1-568 (2010).

Schmid M, Steinlein C, Bogart JP, Feichtinger W, Haaf T, Nanda I, del Pino EM, Duellman WE, Hedges B: The hemiphractid frogs. Phylogeny, embryology, life history, and cytogenetics. Cytogenet Genome Res 138:69-384 (2012).

Schmid M, Smith J, Burt DW, Aken BL, Antin PB, Archibald AL, Ashwell C, Blackshear PJ, Boschiero C, Brown CT, Burgess SC, Cheng HH, Chow W, Coble DJ, Cooksey A, Crooijmans RPMA, Damas J, Davis RVN, de Konig DJ, Delany ME, Derrien T, Desta TT, Dunn IC, Dunn M, Ellegren H, Eöry L, Erb I, Farré M, Fasold M, Fleming D, Flicek P, Fowler KE, Frésard L, Froman DP, Garceau V, Gardner PP, Gheyas AG, Griffin DK, Groenen MAM, Haaf T, Hanotte O, Hart A, Häsler J, Hedges SB, Hertel J, Howe K, Hubbard A, Hume DA, Kaiser P, Kedra D, Kemp SJ, Klopp C, Kniel KE, Kuo R, Lagarrigue S, Lamont SJ, Larkin DM, Lawal RA, Markland SM, McCarthy F, McCormack HA, McPherson MC, Motegi A, Muljo SA, Münsterberg A, Nag R, Nanda I, Neuberger M, Nitsche A, Notredame C, Noyes H, O'Connor R, O’Hare EA, Oler AJ, Ommeh SC, Pais H, Persia M, Pitel F, Preeyanon L, Prieto Barja P, Pritchett EM, Rhoads DD, Robinson CM, Romanov MN, Rothschild M, Roux PF, Schmidt CJ, Schneider AS, Schwartz M, Searle SM, Skinner MA, Smith CA, Stadler PF, Steeves TE, Steinlein C, Sun L, Takata M, Ulitsky I, Wang Q, Wang Y, Warren WC, Wood JMD, Wragg D, Zhou H: Third report on chicken genes and chromosomes 2015 . Cytogenet Genome Res 145:75-180 (2015).

Schmid M, Steinlein C, Haaf T, Feichtinger W, Guttenbach M, Bogart JP, Gruber SL, Kasahara S, Kakampuy W, del Pino EM, Carrilo AB, Romero-Carvajal A, Mahony M, King M, Duellman WE, Hedges SB: The arboranan frogs - evolution, biology, cytogenetics. Cytogenet Genome Res, in press (2018). 